\title{
PREVALENSI INFEKSI VIRAL NERVOUS NECROSIS (VNN) DAN IRIDOVIRUS PADA HATCHERI DAN BUDIDAYA IKAN LAUT
}

\section{Sari Budi Moria Sembiring\#, Gigih Setia Wibawa, Ketut Mahardika, Zeny Widiastuti, dan Haryanti}

\author{
Balai Besar Riset Budidaya Laut dan Penyuluhan Perikanan \\ Jl. Br. Gondol Kec. Gerokgak Kab. Buleleng, Kotak Pos 140, Singaraja 81101, Bali
}

(Naskah diterima: 17 Mei 2018; Revisi final: 31 Agustus 2018; Disetujui publikasi: 3 September 2018)

\begin{abstract}
ABSTRAK
Piscine nodavirus sebagai penyebab penyakit VNN (Viral Nervous Necrosis) dan iridovirus merupakan jenis virus yang dikenal menjadi penyebab utama kematian ikan laut yang dibudidayakan. Virus ini mampu menginfeksi ikan dari ukuran benih sampai ukuran konsumsi dan dalam waktu dua minggu, kematian mencapai 80\% sampai $100 \%$ Pada pembenihan larva dan benih ikan dalam skala rumah tangga ataupun hatcheri lengkap di sepanjang pantai di wilayah Bali Utara sering mengalami infeksi VNN dan iridovirus Namun, informasi terjadinya infeksi belum didata dengan baik. Tujuan penelitian ini untuk memperoleh data dan informasi mengenai peta infeksi atau serangan virus pada pembudidaya/pembenihan ikan sepanjang tahun $2017 \mathrm{di}$ Bali Utara. Sampling dilakukan pada bulan Februari, Mei, Agustus, dan Oktober. Di samping melakukan sampling, juga dilakukan input data dari hasil analisis sampel di laboratorium bioteknologi yang diperoleh dari pemilik hatcheri/pembudidaya ikan. Analisis VNN menggunakan metode IQPus sedangkan analisis iridovirus dengan metode PCR konvensional dengan primer spesifik. Parameter yang diamati adalah prevalensi VNN dan iridovirus dari setiap hatcheri dan keramba jaring apung. Sebagai data penunjang pengukuran parameter kualitas air berupa suhu, salinitas, amoniak, dan nitrit yang dilakukan pada saat pengambilan sampel benih. Hasil penelitian menunjukkan bahwa tingkat infeksi VNN di hatcheri Bali utara terjadi di bulan September sebesar 33,3\%dan iridovirus pada bulan Agustus mencapai 18,61\% Sedangkan tingkat prevalensi VNN tertinggi di KJA terjadi pada bulan Oktober mencapai 83,4\% dan puncak infeksi iridovirus terjadi di bulan Februari dengan nilai prevalensi sebesar 50,0\%
\end{abstract}

KATA KUNCl: $\quad$ prevalensi; VNN; iridovirus; hatcheri; budidaya laut

ABSTRACT: Infection prevalence of viral nervous necrosis (VNN) and iridovirus in hatcheries and mariculture. By: Sari Budi Moria Sembiring, Gigih Setia Wibawa, Ketut Mahardika, Zeny Widiastuti, and Haryanti

\begin{abstract}
VNN and iridovirus are viral diseases causing the highest mortality in mariculture. Theseviruses areable to infect eggs, larvae, juveniles and even marketable size fish. They can cause $80 \%$ to $100 \%$ mortality in just two weeks. Larvae or fingerlings in small or big scale hatcheries in Northern Bali were frequently infected by VNN or Iridovirus. Unfortunately, information about the local disease outbreaks was not well documented. The aim of this research was to collect data and information about the infection of these viruses in hatcheries and floating net cage mariculture in Northern Bali during 2017. Sampling was conducted in February, May, August, and October, 2017. In addition to the primary data from the field activities, disease infection secondary dataset from the fish farmers who analyzed their infected fish in our laboratory were also used. The identification of VNN infection was performed following IQPlus method while Iridovirus was tested using the conventional PCR method with specific primers. The parameters observed were the VNN and Iridovirus prevalence in each hatchery and floating net cage. Water quality parameters were measured in situ such as temperature, salinity, ammonia, and nitrite. The results showed that infection of VNN in hatcheries at Northern Bali, the highest infection was found in September as high as 33.3\%and Iridovirus in August at 18.61\% While in Floating Net Cage the highest infection for VNN was found in October with value of $83.4 \%$ and Iridovirus was found in February with value of $50.0 \%$
\end{abstract}

\section{KEYWORDS: prevalence; VNN; iridovirus; hatcheries; mariculture}

\footnotetext{
\# Korespondensi: Balai Besar Riset Budidaya Laut dan Penyuluhan Perikanan. JI. Br. Gondol Kec. Gerokgak Kab. Buleleng, Kotak Pos 140, Singaraja 81101, Bali, Indonesia. Tel.: + 6236292278

E-mail: moriasembiring@yahoo.co.id
} 


\section{PENDAHULUAN}

Peningkatan permintaan produk perikanan di pasar global, berdampak pada semakin tingginya minat pembudidaya untuk budidaya ikan di Karamba Jaring Apung (KJA). Bahkan di Asia Tenggara, produksi akuakultur telah tumbuh dengan cepat untuk dekade terakhir, dan telah menyokong secara signifikan persediaan pangan di seluruh dunia, serta mampu meningkatkan pendapatan rata-rata untuk banyak negara. Namun intensifikasi akuakultur di banyak negara ini telah menimbulkan penyebaran berbagai penyakit dengan cepat, yang mana merupakan salah satu dari faktor penghalang untuk dapat mendukung produksi komoditas perikanan, terutama selama tahap pemeliharaan larva dan benih dari komoditas budidaya. Kematian yang ditimbulkan oleh penyakit ikan sangat tergantung pada jenis penyakit yang menyerang, kondisi ikan, dan lingkungan. Apabila kondisi lingkungan menurun maka kematian yang diakibatkan oleh wabah penyakit sangat tinggi, tapi sebaliknya apabila kondisi lingkungan baik maka kematian akibat infeksi suatu penyakit lebih rendah (Cole et al., 2009).

VNN dapat menyerang sistem saraf pusat, retina mata, serta organ reproduksi. Penyakit ini umumnya dapat menginfeksi hampir pada seluruh fase pertumbuhan ikan (stadia larva dan benih), serta mortalitasnya dapat mencapai $100 \%$ Penularan penyakit ini dapat terjadi secara vertikal maupun horizontal. Gejala umum VNN antara lain nafsu makan menurun, ikan sangat lemah, warna tubuh pucat, dan gejala spesifik berupa pergerakan yang tidak terkoordinasi, seperti berenang tidak terarah, berputar-putar, hiperaktif, terbalik, serta sering menghentakkan kepala ke atas permukaan air secara sporadik (Yuasa et al., 2001; Gomez \& Baeck, 2008; Yanong, 2016). Sedangkan irido virus sebagai penyebab penyakit Sleepy Grouper Diseases (SGD) dapat bersifat akut sampai kronis dengan morbiditas dan mortalitas yang bervariasi antara 30\%sampai dengan $100 \%$ tergantung pada spesies, umur, serta kondisi lingkungan (Won et al., 2013). Penularan penyakit iridovirus terjadi melalui kontak langsung atau melalui air yang terkontaminasi. Organ target penyakit ini adalah ginjal dan limpa. Gejala klinis ikan yang terinfeksi iridovirus, antara lain warna tubuh ikan gelap, insang pucat, nafsu makan turun, serta pergerakan renang yang lemah dan tidak terkoordinasi. Gejala spesifik yang sering muncul adalah ikan berenang di dasar bak dengan keadaan terbaring pada salah satu sisi tubuhnya (Mahardika et al., 2003; Asrazitah et al., 2014).

Hasil analisis sampel yang diperoleh dari pembenihan ikan kerapu skala rumah tangga ataupun hatcheri lengkap di sepanjang pantai di wilayah Bali Utara sering mengalami infeksi VNN dan iridovirus, namun informasi terjadinya infeksi atau serangan virus pada bulan/musim kemarau, musim hujan atau terjadi pada peralihan musim belum diketahui sehingga dilakukan pemantauan prevalensi infeksi penyakit VNN dan iridovirus setiap bulan dengan tujuan agar diperoleh data dan informasi mengenai peta infeksi atau serangan virus pada pembenihan dan budidaya ikan laut sepanjang tahun 2017 di pantai Bali Utara.

\section{BAHAN DAN METODE}

\section{Sampel Uji}

Sampel uji berupa ikan hibrida (kerapu cantik dan kerapu cantang) dan kakap putih masing-masing 10 ekor. Hewan uji diperoleh dari enam hatcheri dan empat pembudidaya KJA di pantai Bali Utara. Pengambilan sampel ikan dari hatcheri dilakukan tiga periode pada bulan Februari (musim hujan), Mei-Juni (musim kemarau), dan Oktober-November (memasuki musim hujan), sedangkan di pembudidaya ikan (KJA) dilakukan empat periode yaitu bulan Februari (musim hujan); Mei, Agustus (musim kemarau); dan Oktober (memasuki musim hujan). Rata-rata hasil pengukuran panjang total dan bobot badan hewan uji dari hatcheri adalah: 3,14 $\pm 0,26 \mathrm{~cm}$ dan $0,49 \pm 0,09 \mathrm{~g}$; sedangkan ukuran hewan uji dari pembudidaya di KJA sebesar $16,61 \pm 0,95 \mathrm{~cm}$ dan $89,27 \pm 9,96 \mathrm{~g}$. Hatcheri yang di-sampling berada di Desa Gerokgak, Penyabangan, dan Banyupoh; sedangkan untuk pembudidaya ikan di KJA berlokasi di Teluk Panerusan, Desa Sumberkima.

Sebagai data pembanding untuk mengetahui tingkat prevalensi sepanjang tahun 2017 di Bali Utara, juga digunakan data hasil uji dari laboratorium uji bioteknologi yang terakreditasi yang dibawa oleh pemilik untuk dianalisis dan berasal dari hatcheri dan pembudidaya KJA yang jumlah dan waktunya tidak tertentu.

\section{Analisis VNN}

Teknik deteksi VNN dilakukan dengan metode IQPlus. Langkah kerja deteksi virus dengan IQPus meliputi beberapa tahapan antara lain ekstraksi, amplifikasi dan dokumentasi.

\section{Ekstraksi}

Sampel jaringan dari 10 ekor ikan yang digunakan adalah mata atau otak. Bahan yang digunakan untuk ekstraksi sudah tersedia dalam kit yang terdiri atas: solution-1; solution-2; larutan PB3, dan solution-3 sebagai elution buffer. 


\section{Amplifikasi}

Reaksi amplifikasi menggunakan bahan yang telah tersedia di dalam kit IQ ${ }^{\text {Plus }}$ VNN tersebut. Setelah menyiapkan larutan untuk amplifikasi dan memasukkan genom sampel, kemudian proses amplifikasi dilakukan dalam mesin POCKIT PCR dengan panjang gelombang $520 \mathrm{~nm}$. Proses amplifikasi berlangsung selama satu jam dan hasil deteksi langsung terlihat di layar mesin tersebut yang selanjutnya di dokumentasikan menggunakan kamera digital.

\section{Analisis Iridovirus}

Tahapan analisis iridovirus meliputi ekstraksi; amplifikasi, elektroforesis, dan dokumentasi.

\section{Ekstraksi}

Sampel jaringan dari 10 ekor ikan yang digunakan adalah: organ limpa/ginjal. Ekstraksi DNA menggunakan larutan lysis buffer (produk dari IQ -2000) dan tahapan ekstraksi sesuai dengan manual dari kit tersebut.

\section{Amplifikasi}

Amplifikasi menggunakan kit (Promega) dengan primer spesifik untuk iridovirus. Pada saat proses amplifikasi, juga digunakan kontrol positif dari hasil kultur sel dan kontrol negatif berupa nuclease free water. Program amplifikasi sesuai dengan hasil penelitian Kurita et al. (1998).

\section{Elektroforesis}

Elektroforesis menggunakan agarose 1,5\% dalam larutan 1x TAE buffer dan proses elektroforesis berlangsung selama 25 menit.

\section{Dokumentasi}

Setelah selesai proses elektroforesis, untuk mengetahui positif atau negatif sampel yang dianal isis, gel elektroforesis diletakkan di atas alat UV transilluminator. Selanjutnya hasil yang diperoleh didokumentasikan menggunakan Geldoc camera. Sampel yang terinfeksi iridovirus menghasilkan pita pada ukuran 570 bp dan sejajar dengan pita DNA dari positif kontrol.

\section{Parameter yang Diamati}

Parameter yang diamati adalah prevalensi VNN dan Iridovirus dari setiap hatcheri dan KJA. Sebagai data penunjang yaitu pengukuran parameter kualitas air berupa suhu, salinitas, amoniak, dan nitrit yang dilakukan pada saat pengambilan sampel di hatcheri dan KJA. Perhitungan prevalensi menggunakan rumus sebagai berikut:
Prevalensi $=\frac{\text { Ikan sampel yang terinfeksi }}{\text { Total ikan sampel yang diperiksa }} \times 100 \%$

Untuk menganalisis tingkat prevalensi serangan virus VNN dan iridovirus yang menginfeksi ikan laut di hatcheri dan pembudidaya di Bali Utara, semua data yang diperoleh dihimpun dalam bentuk tabulasi selanjutnya dianalisis secara deskriptif.

\section{HASIL DAN BAHASAN}

Masalah utama dalam budidaya ikan hingga saat ini salah satunya adalah tentang penyakit. Penyakit ini menyebabkan kerugian ekonomis karena dapat menyebabkan pertumbuhan terhambat, periode pemeliharaan lebih lama, tingginya konversi pakan, padat tebar yang tinggi, dan kematian ikan, sehingga dapat mengakibatkan menurunnya atau hilangnya produksi (Abdullah et al., 2017).

Hasil deteksi VNN dan iridovirus pada sampel ikan yang dianalisis, jika terinfeksi VNN akan terlihat tanda positif $(+)$ di layar mesin IQ Plus (Gambar 1), dan kategori sampel yang terinfeksi iridovirus terlihat satu pita dari hasil elektroforesis dengan target $570 \mathrm{bp}$ (Gambar 2).

Sampel hewan uji yang diperoleh dari beberapa hatcheri di pantai Bali Utara hampir 90\%adalah kerapu hibrida (cantik \& cantang) dan 10\%nya adalah ikan kakap putih. Hasil deteksi VNN dan iridovirus dari sampel uji hatcheri terlihat pada Gambar 3.

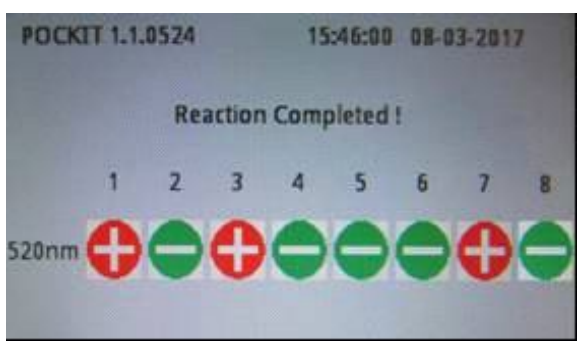

Gambar 1. Hasil deteksi VNN dengan metode $\mathrm{IQ}^{\text {Plus }}$ terhadap sampel uji dari hatcheri dan pembudidaya KJA (1, $3=$ sampel uji yang terinfeksi VNN; $2,4,5$, dan $6=$ sampel uji yang tidak terinfeksi VNN; 7= kontrol positif VNN; dan 8= kontrol negatif).

Figure 1. Detection result of VNN using IQPlus method for fish sampled from hatcheries and floating net cages (1, 3 were infected with VNN; 2, 4, 5, and 6 were not infected with VNN; 7 was positive control; and 8 was negative control). 


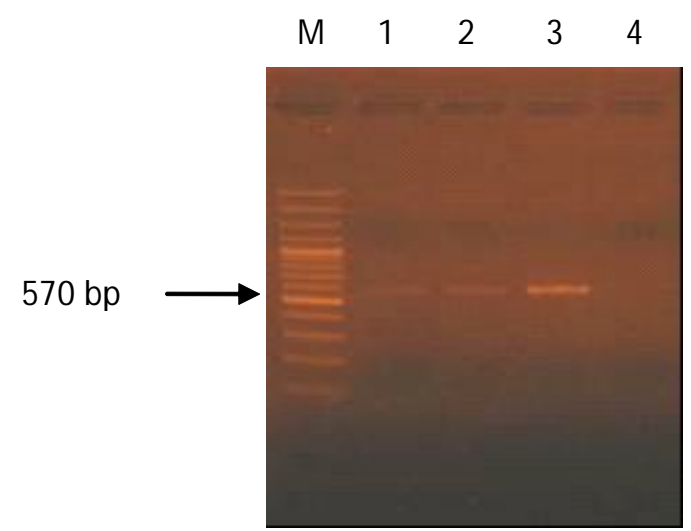

Gambar 2. Hasil deteksi iridovirus menggunakan metode PCR konvensional ( $M=$ marker 100 bp; 1-2= sampel uji yang terinfeksi iridovirus; $3=$ kontrol positif iridovirus; $4=$ kontrol negatif).

Figure 2. Detection result of Iridovirus using the conventional PCR method ( $M$ : marker 100 bp; 1-2 were infected by Iridovirus; 3: positive control; and 4: negative control).

Ikan terinfeksi VNN terjadi pada bulan Februari dan Oktober-November, sedangkan untuk parameter iridovirus semua sampel uji tidak terinfeksi virus tersebut. Pada bulan Agustus tidak dapat dilakukan sampling di hatcheri akibat ikan yang dipelihara sebagian besar mengalami kematian akibat terinfeksi VNN.

Sampel uji dari hasil sampling di KJA hampir 95\% ikan yang dibudidayakan adalah kerapu cantik dan cantang dan sekitar 5\%memelihara ikan kakap putih. Hasil deteksi VNN dan iridovirus dari sampel KJA terlihat pada Gambar 4.
Ikan yang terinfeksi VNN di KJA terjadi pada bulan Februari, Agustus, dan Oktober, sedangkan yang terinfeksi iridovirus terjadi pada saat sampling di bulan Februari. Apabila dilihat dari pola infeksi VNN baik di hatcheri maupun KJA hampir sama, hal ini diduga karena pada bulan tersebut terjadi fluktuasi suhu air yang tinggi, dan ini terlihat dari salah satu hasil pemantauan suhu menggunakan alat logger pada bulan Februari di KJA (Gambar 5). Berdasarkan Gambar 5, terlihat bahwa fluktuasi suhu di bulan Februari sangat tinggi yaitu antara $27,7^{\circ} \mathrm{C}$ sampai $32,45^{\circ} \mathrm{C}$. Hal ini yang menyebabkan ikan mengalami stres, nafsu makan berkurang, tingkat imunitas menurun, dan apabila ada serangan penyakit akan menyebabkan kematian. Hal ini sesuai dengan pendapat Nakajima et al. (1997), menyatakan bahwa lingkungan yang terkontaminasi dan kualitas air yang buruk memicu peningkatan infeksi iridovirus. Hal ini utamanya disebabkan oleh kontak langsung antara insang dan saluran pencernaan ikan dengan lingkungan. Penyebaran virus antara ikan yang berada disistem produksi yang sama akan terjadi dengan sangat cepat bila ikan tidak memiliki sistem imun yang baik dan berada dalam kondisi lemah (Manin \& Ransangan, 2011). Selanjutnya menurut Cao et al. (2007), pemicu terjadinya serangan penyakit di antaranya adalah ketidakseimbangan antara daya dukung lingkungan dengan kuantitas produksi dalam satu areal budidaya (infeksi tidak seimbang antara ikan, patogen, dan lingkungannya).

Dari hasil penelitian Lio-Po \& De la Pena (2004), menunjukkan bahwa suhu mempunyai peranan penting dalam proses replikasi dan peningkatan sifat patogenitas dari Piscine nodavirus. Sebagai contoh: RGNNV yang diisolasi dari ikan kerapu menghasilkan efek cytopathic pada sel GF-1 pada suhu $24^{\circ} \mathrm{C}-32^{\circ} \mathrm{C}$ tetapi tidak pada suhu $20^{\circ} \mathrm{C}$ atau $37^{\circ} \mathrm{C}$. Pada larva yang

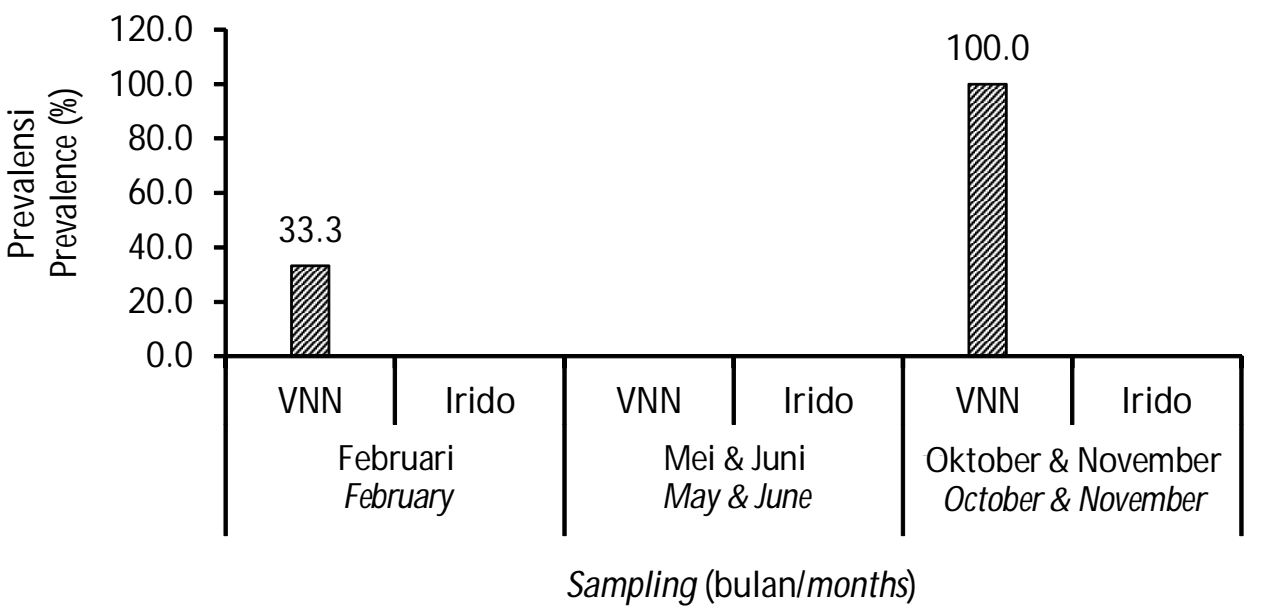

Gambar 3. Prevalensi VNN dan Iridovirus dari hasil sampling di hatcheri.

Figure 3. VNN and iridovirus prevalence values sampled from hatcheries. 


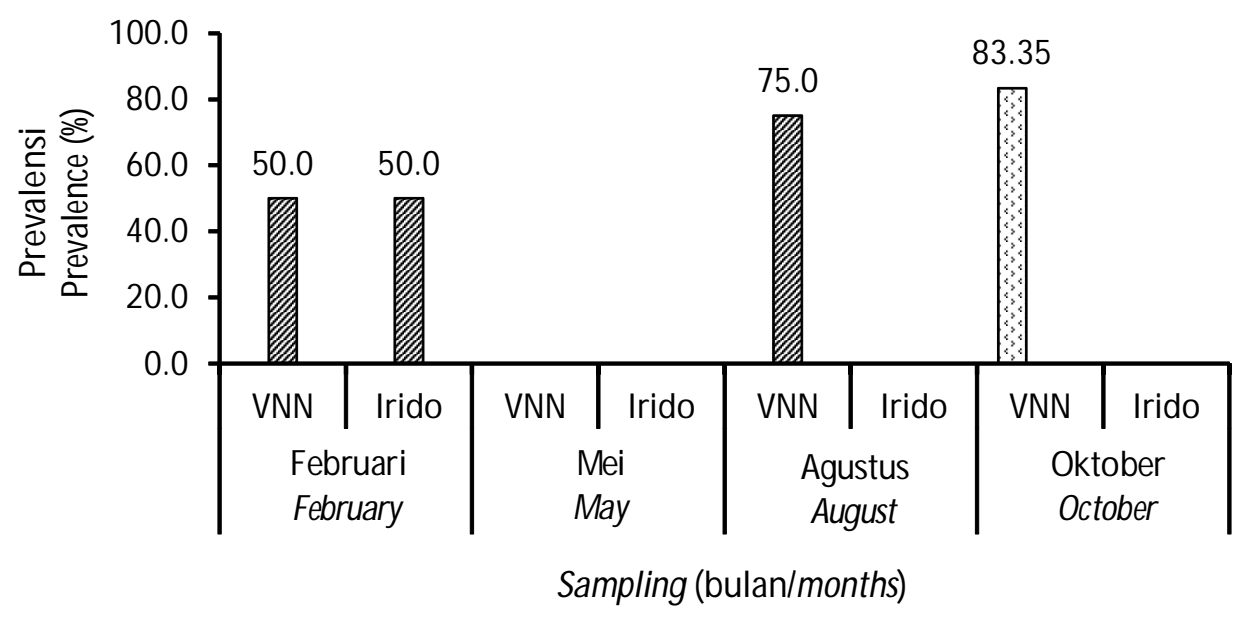

Gambar 4. Prevalensi VNN dan Iridovirus dari hasil sampling di KJA.

Figure 4. VNN and iridovirus prevalence values sampled from floating net cages.

diuji tantang dengan RGNNV pada suhu $28^{\circ} \mathrm{C}$, kematian mencapai 100\%pada 50-80 jam setelah inokulasi. Pada uji coba yang dilakukan pada benih ikan kerapu $\mathrm{E}$. akaara, RGNNV menyebabkan kematian hingga $100 \%$ pada suhu $24^{\circ} \mathrm{C}-28^{\circ} \mathrm{C}$, namun pada suhu $16^{\circ} \mathrm{C}$ dan $20^{\circ} \mathrm{C}$, mortalitas berkurang hingga $57 \% 61 \%$ dan munculnya perilaku berenang yang tidak normal tetapi tidak menyebabkan kematian pada ikan tersebut.

Pada saat sampling di hatcheri dan KJA juga dilakukan pengamatan kualitas air (Tabel 1). Secara umum, hasil pengamatan kualitas air untuk sampel yang diperoleh pada saat sampling dalam kriteria kesesuaian untuk pembenihan dan budidaya ikan laut, namun di bulan Agustus dan Oktober pada beberapa KJA untuk salinitas cenderung tinggi (35-36 ppt) dibandingkan dengan bulan Februari dan Mei. Apabila terjadi fluktuasi salinitas yang cukup tinggi juga akan mengganggu semua fisiologis ikan dan bahkan menyebabkan ikan menghabiskan energi hanya untuk menormalkan fungsi tubuh dan bukan untuk pertumbuhan (Landau, 1995). Hal ini yang menyebabkan pada bulan Agustus dan Oktober tingkat prevalensi VNN tinggi. Menurut Amal et al. (2015) dan Ismail et al. (2016), menyatakan bahwa kualitas air yang tidak optimal akan mendukung pertumbuhan patogen pada ikan yang dibudidayakan dan juga lingkungannya. Selanjutnya Snieszko (1978) juga menyatakan bahwa perkembangan penyakit dalam sistem akuakultur adalah proses yang kompleks dan sangat tergantung pada interaksi antarainang, lingkungan, dan patogen.

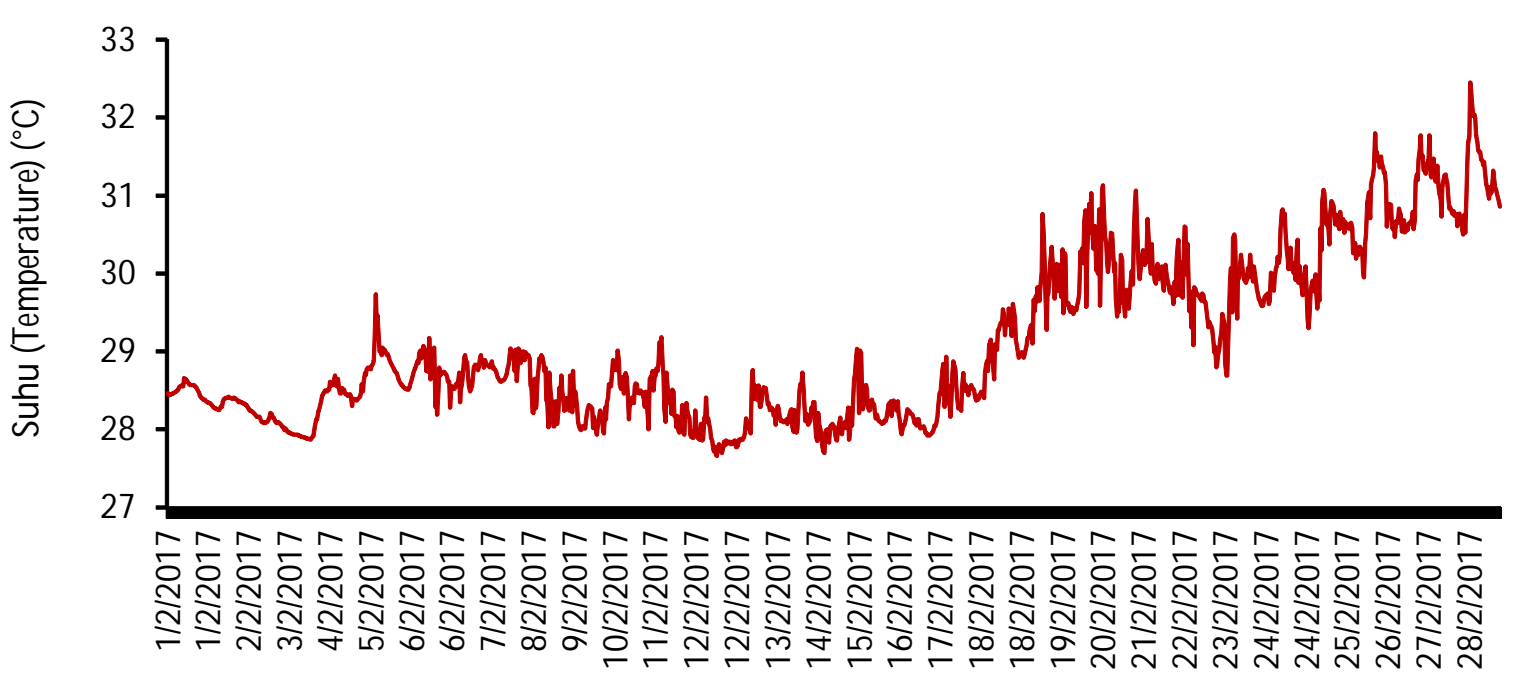

Waktu (hari) / Time (days)

Gambar 5. Pengamatan suhu air laut pada bulan Februari di KJA menggunakan alat logger.

Figure 5. Sea water temperature variation during the month of February 2017 in floating net cages using a data logger. 
Tabel 1. Hasil analisis kualitas air di hatcheri dan keramba jaring apung

Table 1. Sea water quality measured at hatchery and floating net cages

\begin{tabular}{lcccc}
\hline \multirow{2}{*}{$\begin{array}{c}\text { Bulan } \\
\text { Months }\end{array}$} & \multicolumn{4}{c}{ Parameter (Parameters) } \\
\cline { 2 - 5 } & $\begin{array}{c}\text { Suhu } \\
\text { Temperature ('C) }\end{array}$ & $\begin{array}{c}\text { Salinitas } \\
\text { Salinity (ppt) }\end{array}$ & $\begin{array}{c}\text { Amoniak } \\
\text { Ammonia (mg/L) }\end{array}$ & $\begin{array}{c}\text { Nitrit } \\
\text { Nitrite (m } \mathbf{( m / L )}\end{array}$ \\
\hline Hatcheri (Hatchery) & & & & \\
$\quad$ Februari (February) & $19.2 \pm 0.4$ & $33.0 \pm 1.0$ & $0.36 \pm 0.04$ & $0.10 \pm 0.06$ \\
Mei (May) & $23.0 \pm 1.2$ & $34.1 \pm 0.5$ & $0.01 \pm 0.001$ & $0.02 \pm 0.0$ \\
Oktober (October) & $27.2 \pm 0.2$ & $34.0 \pm 0.0$ & $0.21 \pm 0.12$ & $<0.01 \pm 0.0$ \\
\hline Keramba jaring apung (Floating net cage) & & & & \\
$\quad$ Mei (May) & $29.1 \pm 0.1$ & $33.0 \pm 1.0$ & $0.02 \pm 0.0$ & $<0.003 \pm 0.0$ \\
Agustus(August) & $27.9 \pm 0.2$ & $35.4 \pm 0.5$ & $0.02 \pm 0.004$ & $<0.003 \pm 0.0$ \\
Oktober (October) & $28.5 \pm 0.3$ & $35.0 \pm 0.0$ & $0.03 \pm 0.005$ & $<0.003 \pm 0.0$ \\
\hline
\end{tabular}

Data tingkat prevalensi VNN dan iridovirus dari hasil sampling di hatcheri dan KJA tersebut, jika dibandingkan dengan kompilasi data hasil analisis dari pelanggan hatcheri di laboratorium bioteknologi yang terakreditasi, ternyata menunjukkan pola yang sama untuk prevalensi VNN dan iridovirus (Gambar 6). Pola ikan yang terinfeksi VNN di hatcheri di sepanjang pantai Bali Utara setiap bulan ada yang terinfeksi, namun nilai prevalensi yang tinggi terjadi di bulan Agustus dan September yaitu 27,3\% dan 33,3\% Sedangkan infeksi iridovirus di hatcheri puncaknya terjadi pada bulan Agustus dengan nilai prevalensi sebesar 18,6\%(Gambar 6).
Apabila dilihat dari Gambar 6, ternyata pada bulan September, ikan yang paling banyak terinfeksi VNN adalah kerapu cantik dan kerapu cantang. Sedangkan untuk iridovirus, nilai prevalensi yang tertinggi terjadi di bulan Agustus sebesar 18,6\%dengan jenis ikan yang paling banyak terinfeksi adalah kerapu cantang. Nilai prevalensi yang tinggi ini juga disebabkan kondisi perairan di pantai Bali utara yang kualitasnya sudah mulai menurun. Salah satu pemicu menurunnya kualitas perairan, misalnya akibat tingginya kandungan bahan organik akibat buangan limbah dari daratan.

Hasil diagnosis klinis di lapangan menunjukkan bahwa ikan yang diduga terinfeksi oleh VNN

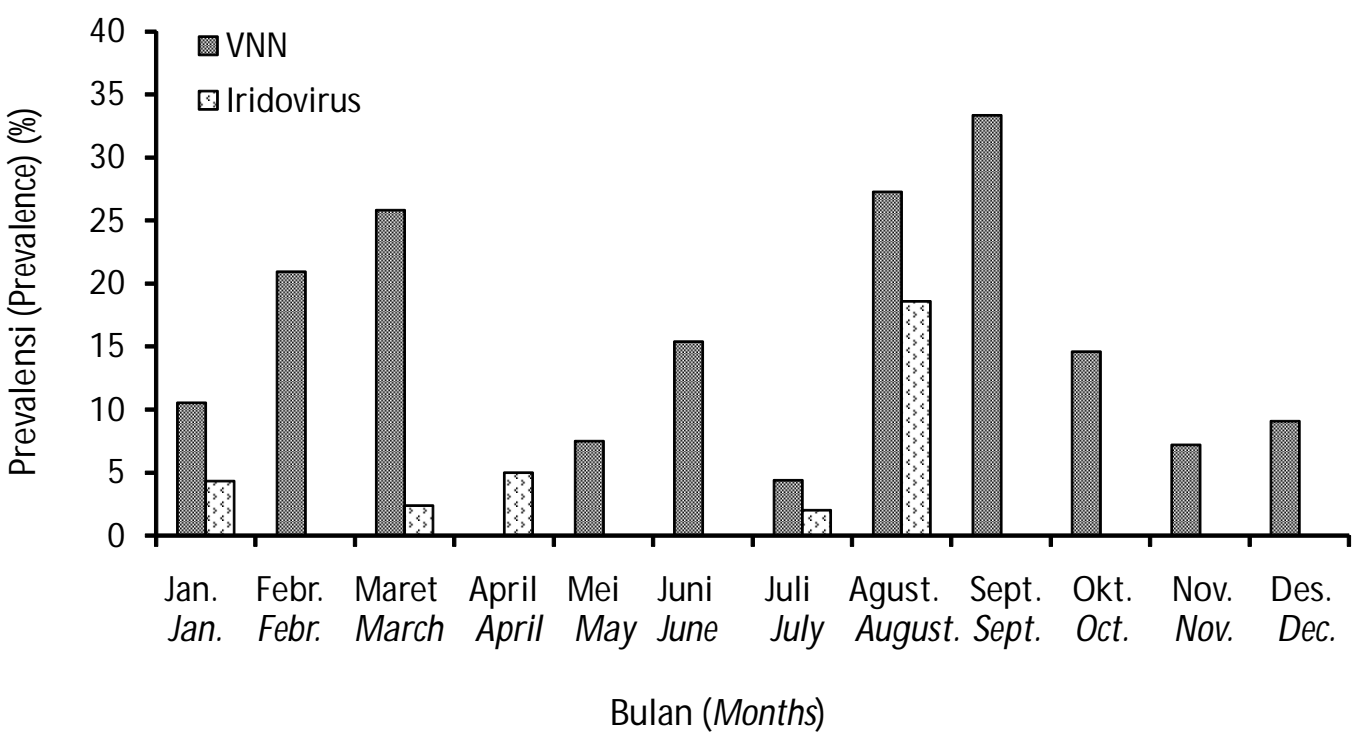

Gambar 6. Grafik prevalensi VNN dan iridovirus setiap bulan di hatcheri di lokasi Bali Utara (data hasil uji dari laboratorium uji bioteknologi yang terakreditasi).

Figure 6. Monthly prevalence values of VNN and iridovirus infections in the hatcheries located in North Bali (Data source were from fish samples tested in the laboratory). 
memperlihatkan gejala pergerakan renang yang tidak beraturan dan bahkan cenderung terbalik, nafsu makan selama masa pemeliharaan kurang dan memiliki kerusakan pada organ mata. Kondisi ini sesuai dengan hasil penelitian yang dilakukan oleh Lio-Po $\&$ de la Pena (2004) yang menyatakan bahwa umumnya ikan yang terinfeksi oleh VNN akan menyebabkan ikan menunjukkan perilaku berenang yang tidak beraturan, warna tubuh terlihat lebih gelap, dan nafsu makan berkurang.

Berdasarkan data hasil analisis parameter VNN mulai dari bulan Januari sampai Desember, terlihat bahwa setiap bulan di hatcheri ada yang terinfeksi VNN. Hal ini menunjukkan bahwa penyebaran VNN dapat terjadi di antara hatcheri dengan mudah melalui peralatan yang terkontaminasi (Munday \& Nakai, 1997); air yang terkontaminasi (Ransangan \& Manin, 2012); dan melalui kontak fisik dengan ikan pembawa penyakit (Manin \& Ransangan, 2011). Selain itu, suhu air juga berpengaruh terhadap kelangsungan hidup virus VNN. Infeksi virus VNN di suhu perairan $27^{\circ} \mathrm{C}-31^{\circ} \mathrm{C}$ dilaporkan mampu menyebabkan kematian pada ikan kerapu bebek (Cromileptes altivelis), sedangkan peningkatan suhu di $35^{\circ} \mathrm{C}$ dapat menghambat perkembangbiakan virus VNN yang ditunjukkan dengan penurunan kematian ikan (Yuasa et al., 2007). Selanjutnya menurut Hata et al. (2007), suhu optimum untuk perkembangbiakan virus VNN isolat RGNNV (redspotted grouper nervous necrosis virus) berkisar antara $25^{\circ} \mathrm{C}-30^{\circ} \mathrm{C}$. Lebih lanjut dilaporkan bahwa patogenisitas dari virus VNN akan menurun pada suhu $>37^{\circ} \mathrm{C}$. Hal tersebut, diduga bahwa keberadaan ikan yang bersifat carier VNN, suhu perairan laut dikisaran $25^{\circ} \mathrm{C}-32^{\circ} \mathrm{C}$ dan tidak diaplikasikannya sistem biosekuriti yang baik pada hatcheri yang mengakibatkan tingkat prevalensi di Bali Utara cukup tinggi.

Demikian juga hasil diagnosa di pembudidaya (KJA) pada bulan Februari memperlihatkan gejala klinis yang memperkuat dugaan bahwa ikan terinfeksi oleh iridovirus seperti gerakan renang yang lemah dan bahkan seperti diam di dasar jaring pemeliharaan, nafsu makan menurun, mengalami anemia yang berat, bercak merah pada insang, dan terdapat pembengkakan pada beberapa organ seperti limpa dan ginjal. Hasil penelitian yang dilakukan oleh Johnny \& Roza (2009), juga menyatakan bahwa umumnya ikan yang terinfeksi oleh iridovirus akan menunjukkan gejala klinis berenang lemah atau diam di dasar air sehingga sering disebut sebagai penyakit tidur. Menurut Lio-Po \& De la Pena (2004), lingkungan yang terkontaminasi dan kualitas air yang buruk memicu peningkatan infeksi VNN dan iridovirus. Selanjutnya OIE (2006), menyatakan bahwa wabah iridovirus umumnya terjadi pada musim panas atau ketika suhu lingkungan berada di atas suhu $25^{\circ} \mathrm{C}$.

Infeksi VNN dan iridovirus pada hatcheri dan budidaya ikan laut di Bali Utara sering terjadi dan situasi ini akan sangat berdampak terhadap peningkatan dan keberlanjutan produksi budidaya ikan laut. Oleh karena itu, pemilik hatcheri dan budidaya ikan harus menerapkan sistem biosekuriti yang baik.

\section{KESIMPULAN DAN SARAN}

Infeksi VNN pada hatcheri dan budidaya ikan laut di Bali Utara sering terjadi dengan tingkat prevalensi yang tertinggi di KJA terjadi pada bulan Oktober sebesar $83,35 \%$ dan infeksi iridovirus tertinggi terjadi pada bulan Februari sebesar $50 \%$

Tingkat prevalensi VNN tertinggi pada hatcheri terjadi pada bulan September mencapai 33,33\% sedangkan infeksi iridovirus tertinggi terjadi di bulan Agustus mencapai 18,6\%

Dalam mempertahankan laju produksi dan membuat produk hasil budidaya semakin kompetitif, program biosekuriti harus diterapkan di seluruh fasilitas, sarana, prasarana, serta berbagai faktor pendukung lainnya.

\section{UCAPAN TERIMA KASIH}

Penelitian ini dibiayai dari APBN dalam DIPA Balai Besar Riset Budidaya Laut dan Penyuluhan Perikanan Gondol tahun 2017. Pelaksanaan penelitian dapat berlangsung dengan baik atas bantuan teknisi litkayasa Ni Luh Tati Aryani, Deny Puji Utami, dan Dadang Rusmana. Dan tentu bantuan berupa masukan dan saran atas tulisan oleh Prof. Dr. Ketut Sugama. Untuk itu, penulis mengucapkan terima kasih.

\section{DAFTAR ACUAN}

Abdullah, A., Ramli, R., Ridzuan, M.S.M., Murni, M., Hashim, S., Sudirwan, F., Abdullah, S.Z., Mansor, M.N., Amira, S., Saad, M.Z., \& Amal, M.N.A. (2017). The presence of vibrionaceae, betanodavirus and iridovirus in marine cage cultured fish: Role of fish size, water physicochemical parameters and relationships among the pathogens. Aquaculture Reports, 7, 57-65.

Amal, M.N.A., Zamri-Saad, M., Siti-Zahrah, A., \& Zulkafli, A.R. (2015). Water quality influences the presence of Streptococcus agalactiae in cage cultured red hybrid tilapia, Oreochromis niloticus $x$ Oreochromis mossambicus. Aquac. Res., 46, 313-323.

Asrazitah, A.R., Julian, R., \& Ahemad, S. (2014). First report of Megalocytivirus (Iridoviridae) in grouper 
culture in Sabah Malaysia. Inter. J. Curr. Microbiol. Appl. Sci., 3, 896-909.

Cao, L., Wang, W., Yang, Y., Yang, C., Yuan, Z., Xiong, S., \& Diana, J. (2007). Environmental impact of aquaculture and countermeasures to aquaculture pollution in China. Environmental Science in Pollution Res., 14(7), 452-46.

Cole, D.W., Cole, R., Gaydos, S.J., Gray, J., Hyland, G., Jacques, M.L., Powell-Dunford, N., Sawhney, C., \& Au, W.W. (2009) Aquaculture: Environmental, toxicological, and health issues. International Journal of Hygiene and Environmental Health, 212(4), 369-377.

Gomez, D.K. \& Baeck, G.W. (2008) Genetic analysis of betanodaviruses in subclinically infected aquarium fish and invertebrates. Springer Science, 56, 499-504.

Hata, N., Okinaka, Y., Sakamoto, T., Iwamoto, T., \& Nakai, T. (2007). Upper temperature limits for the multiplication of betanodaviruses. Fish Pathol., 42(4), 225-228.

Ismail, N.I.A., Amal, M.N.A., Shohaimi, S., Zamri-Saad, M., \& Siti-Zahrah, A. (2016). Associations of water quality and bacteria presence in cage cultured red hybrid tilapia, Oreochromis niloticus $\times 0$. mossambicus. Aquac. Rep., 4, 57-65.

Jhonny, F. \& Roza, D. (2009). Kasus infeksi virus irido pada benih ikan kerapu pasir Epinephelus corallicola di hatcheri. Jurnal Perikanan, 11, 8-12.

Kurita, J., Nakajima, K., Hirono, I., \& Aoki, T. (1998). Polymerase chain reaction (PCR) amplification of DNA of red sea bream iridovirus (RSIV). Fish Pathol., 33, 17-23.

Landau, M. (1995). Introduction to aquaculture. New York: John Willey and Sons, Inc., 440 pp.

Lio-Po, G.D. \& de la Pena, L.D. (2004). Viral diseases. Diseases of Cultured Grouper. ESAFDEC Government of Japan Trust Fund. Lo, Benny K. Antibody Engineering. Method and Protocols. Humana Press, $562 \mathrm{pp}$.

Mahardika, K., Koesharyani, I., Prijono, A., \& Yuasa, K. (2003). Infeksi iridovirus pada induk kerapu lumpur (Epinephelus coioides). Jurnal Penelitian Perikanan Indonesia, 9(1), 49-54.

Manin, B.O. \& Ransangan, J. (2011). Experimental evidence of horizontal transmission of Betanodavirus in hatcheri produced Asian seabass, Lates calcarifer and brown marbled grouper, Epinephelus fuscogutattus fingerling, Aquaculture, 321, 157-165.

Munday, B.L. \& Nakai, T. (1997). Special topic review: Nodaviruses as pathogens in larval and juvenile marine finfish. World Journal of Microbiology and Biotechnology, 13, 375-381.

Nakajima, K., Maeno, Y., Kurita, J., \& Inui, Y. (1997). Vaccination against red seabream iridoviral disease in red seabream. Fish pathology, 18, 99-101.

OIE. (2006). Manual of diagnostic test for aquatic animals. Red Sea Bream Iridoviral Disease. Capter 2.1.15.

Ransangan, J. \& Manin, B.O. (2012). Genome analysis of Betanodavirus from cultured marine fish species in Malaysia. Veterinary Microbiology, 156, 1644.

Snieszko, S.F. (1978). Control of fish diseases. U.S. Nat. Fish. Ser. Mar. Fish. Rev., 40, 65-68.

Won, K.M., Cho, M.Y., Park, M.A., Jee, B.Y., Myeong, J.I., \& Kim, J.W. (2013). First report of Megalocytivirus infection in farmed starry flounder, Platichthys stellatus, in Korea. Fish Aquat. Sci., 16(2), 93-99.

Yanong, R.E.P. (2016). Viral nervous necrosis (Betanodavirus) infections in fish. Department of Fisheries and Aquatic Sciences, UF/IFAS Extension. University of Florida, 6 pp.

Yuasa, K., Koesharyani, I., Roza, D., Johnny, F., \& Zafran. (2001). Manual for PCR procedure; rapid diagnosis on viral nervous necrosis (VNN) in grouper. Lolitkanta - JICA Booklet No 13: 35 pp.

Yuasa, K., Koesharyani, I., \& Mahardika, K. (2007) Effect of high water temperature on Betanodavirus infection of fingerling humpback grouper Cromileptes altivelis. Fish Pathol., 42(4), 219-221. 